\title{
The Association between Risk Factors and Blood Pressure in the Textile Industry Workers
}

\author{
Sumardiyono, ${ }^{1}$ Hartono, ${ }^{2}$ Ari Probandari, ${ }^{1}$ Prabang Setyono ${ }^{3}$ \\ ${ }^{1}$ Department of Public Health, ${ }^{2}$ Department of Physiology, Faculty of Medicine, Universitas Sebelas Maret, \\ Surakarta, Indonesia, ${ }^{3}$ Department of Biology, Faculty of Mathematics and Natural Sciences, \\ Universitas Sebelas Maret, Surakarta, Indonesia
}

\begin{abstract}
Noise exposure is often found in the industrial environment that exposed workers at risk for increasing blood pressure. This study aimed at investigating the association between noise level, duration of noise exposure, age, use of earplugs, and body mass index with blood pressure on textile industry workers. An observational study with the cross-sectional design conducted during August to October 2016. The study population was 180 textile industry workers in Surakarta selected by consecutive sampling method. Statistical analysis used was multiple logistic regression. Results showed that variables associated with systolic blood pressure were the use of earplugs $(\mathrm{OR}=12.7)$, noise level (OR=7.2), body mass index $(\mathrm{OR}=5.3)$, age $(\mathrm{OR}=4.4)$ and duration of noise exposure $(\mathrm{OR}=3.5)$. Variables associated with diastolic blood pressure were the use of earplugs ( $\mathrm{OR}=6.9)$, age $(\mathrm{OR}=6.6)$, noise level $(\mathrm{OR}=6.1)$, body mass index $(\mathrm{OR}=4.4)$, and duration of noise exposure $(\mathrm{OR}=3.1)$. In clonclusion, the risk factors for blood pressure increased among industrial workers are the use of earplug, noise level, body mass index, age and duration of noise exposure.
\end{abstract}

Key words: Blood pressure, textile industry workers

\section{Asosiasi antara Faktor Risiko dan Tekanan Darah pada Pekerja Industri Tekstil}

\begin{abstract}
Abstrak
Paparan kebisingan yang mengekspos pekerja sering ditemukan di lingkungan industri sehingga berisiko terjadi peningkatan tekanan darah. Penelitian ini bertujuan mengetahui hubungan tingkat kebisingan, durasi paparan kebisingan, usia, penggunaan sumbat telinga, dan indeks massa tubuh dengan tekanan darah pada pekerja industri tekstil. Penelitian ini menggunakan jenis observasional dengan desain cross-sectional yang dilakukan pada bulan Agustus-Oktober 2016. Populasi penelitian adalah pekerja industri tekstil di Surakarta. Terpilih 180 orang pekerja dengan menggunakan metode sampling konsekutif. Analisis statistik yang digunakan adalah regresi logistik berganda. Variabel yang berhubungan dengan tekanan darah sistole adalah penggunaan sumbat telinga $(\mathrm{OR}=12,7)$, tingkat kebisingan $(\mathrm{OR}=7,2)$, indeks massa tubuh $(\mathrm{OR}=5,3)$, usia $(\mathrm{OR}=4,4)$, dan durasi paparan kebisingan $(\mathrm{OR}=3,5)$. Variabel yang terkait dengan tekanan darah diastole adalah penggunaan sumbat telinga $(\mathrm{OR}=6,9)$, usia $(\mathrm{OR}=6,6)$, tingkat kebisingan $(\mathrm{OR}=6,1)$, indeks massa tubuh $(\mathrm{OR}=4,4)$, dan durasi paparan kebisingan $(\mathrm{OR}=3,1)$. Simpulan, faktor risiko peningkatan tekanan darah di kalangan pekerja industri tekstil adalah penggunaan sumbat telinga, tingkat kebisingan, indeks massa tubuh, usia, dan durasi paparan kebisingan.
\end{abstract}

Kata kunci: Pekerja industri tekstil, tekanan darah

Correspondence: Sumardiyono, S.K.M., M.Kes. Department of Public Health, Faculty of Medicine, Universitas Sebelas Maret. Gedung Pendidikan Dokter Lantai 7. Jln. Ir. Sutami 36 A, Surakarta 57126, Central Java, Indonesia. Telepon: (62271) 635819. Fax: (62271) 635819. HP: 08562838920; 081288987552. E-mail: sumardiyono_uns@yahoo.com 


\section{Introduction}

Noise is a physically dangerous risk commonly encountered in the workplace of the textile industry. The effects of noise exposure on health are auditory and non-auditory disorders. ${ }^{1}$ The impact on auditory is the noise-induced hearing loss (NIHL) which is the primary concern of workers' health in various countries. While the effects on non-auditory is a change in the endocrine system that causes an increase in blood pressure and heart rate. ${ }^{2}$ An uncontrolled high blood pressure, or hypertension causes damage to arteries and it also a risk factor for stroke, heart attack, and other cardiovascular problems. ${ }^{3}$ Hypertension is the leading risk factor for death and disability globally, where more than twothirds of people with hypertension live. ${ }^{4}$ In 2010 , an estimated 9.4 million deaths were due to hypertension. 5

Previous research in several countries have shown the noise level of the weaving machines of $88 \mathrm{~dB}(\mathrm{~A})$ in Sudan, ${ }^{6} 95 \mathrm{~dB}(\mathrm{~A})$ in Srilanka ${ }^{7}$ and $95.3 \mathrm{~dB}(\mathrm{~A})$ in Pakistan. ${ }^{8}$ In Iran, the noise level of the spinning machine was 97-90 $\mathrm{dB}(\mathrm{A})$ and the weaving machine was $99-100 \mathrm{~dB}(\mathrm{~A}){ }^{9}$ In Indonesia, we measured the noise level of the weaving machine was $98 \mathrm{~dB}(\mathrm{~A})$ in Surakarta as the place to do this research.

In addition to noise, several factors that can increase blood pressure in workers in the textile industry are age, ${ }^{10,11}$ use of hearing protection devices, ${ }^{12}$ bodies mass index, ${ }^{13}$ and duration of noise exposure. ${ }^{12}$ Increasing age can increase blood pressure especially after 40 years old. ${ }^{11}$ The use of an undisciplined hearing protective device at work will also increase the risk of increased blood pressure. ${ }^{12}$ Obesity in workers is also at risk of increasing blood pressure than the ideal body weight, ${ }^{13}$ more extended time off work $(9.6+7.8$ years) will be more risky for increased blood pressure because every day the worker is exposed to noise. ${ }^{14}$

The objective of this study was to examine the association of risk factors that influence blood pressure increase (age, use of hearing protection, body mass index, and duration of noise exposure) with systolic blood pressure and diastolic blood pressure in textile industry workers in Surakarta.

\section{Methods}

The research was an observational analytic study with a cross-sectional design. The study conducted during August to October 2016. The study population was textile industry workers in Surakarta, Indonesia. Samples were selected consecutively using the cluster random sampling technic (participants consisted of two groups, i.e., groups exceeding the threshold limit value (TLV) and those less than the TLV (the TLV limit is $85 \mathrm{dBA}$ ), and groups use earplugs and not use earplugs, determined randomly). The number of samples was 180 people (exposed to noise over $\mathrm{TLV}=99$ people, and below $\mathrm{TLV}=81$ people, and use of earplugs $=74$ people and not use of earplugs $=106$ people).

We used a checklist for information on age, used of earplugs, and duration of noise exposure. Sound level meter type Sanfix GM1356 to measure noise level, height meter type SZ-200, and body scale to measure body mass index, sphygmomanometer type GM-0194SM and its accessories to measure blood pressure in this research.

The measurement of noise level set on the nominal. Other checklist used to collect data on age, use of hearing protection devices, body mass index, the duration of noise exposure, systolic blood pressure, and diastolic blood pressure. Statistical analysis used was multiple logistic regression. Relationships between variables were analyzed using SPSS, version 16.0. The level of statistical significance was set at $\mathrm{p}<0.05$.

\section{Results}

Participants of this study were textile industry workers in Surakarta, Indonesia. They exposed to noise more than $85 \mathrm{~dB}(\mathrm{~A})$ in the department of drawing, winding, roving, pallets, spinning, and weaving which the average noise intensity was 91.4 $\mathrm{dB}(\mathrm{A})$. Intensity less than $85 \mathrm{~dB}(\mathrm{~A})$ found in the office administration department, warehouse administration, blowing, warping, carding, inspecting, finishing, quality control, and packing which the average noise intensity was 79.1 dB(A). The frequency distribution of the results of the complete variable measurement, which includes age, use of hearing protection devices, body mass index, the duration of noise exposure, systolic blood pressure, and diastolic blood pressure are shown in Table 1.

All of the independent variables shown in Table 1 were further tested by multiple logistic regression analysis to determine their associations with systolic blood pressure. The relationship between noise level, age, use of 
230 Sumardiyono dkk.: The Association between Risk Factors and Blood Pressure in the Textile Industry Workers

Table 1 Frequency Distribution of Variables $(n=180)$

\begin{tabular}{lcc}
\hline Characteristics & Total (Person) & Persentage (\%) \\
\hline Noise level (dBA) & & \\
$\quad \leq$ TLV & 81 & 45.0 \\
$\quad>$ TLV & 99 & 55.0 \\
Age (years old) & 107 & \\
$\quad \leq 40$ & 73 & 59.4 \\
$\quad>40$ & & 40.6 \\
$\quad$ Use of earplugs & 74 & 41.1 \\
$\quad$ Using & 106 & 58.9 \\
$\quad$ Not using & & \\
Body mass index $\left(\mathrm{kg} / \mathrm{m}^{2}\right)$ & 104 & 57.8 \\
$\quad$ Ideal & 76 & 42.2 \\
$\quad$ Overweight & & \\
Duration of noise exposure (years) & 79 & 43.9 \\
$\quad \leq 10$ & 101 & 56.1 \\
$\quad>10$ & & \\
Systolic blood pressure (mmHg) & 120 & 66.7 \\
$\quad \leq 120$ & 60 & 33.3 \\
$\quad>120$ & & \\
Diastolic blood pressure (mmHg) & 126 & 70.0 \\
$\quad \leq 80$ & 54 & 30.0 \\
$\quad>80$ & & \\
\hline
\end{tabular}

Table 2 Results of the Multiple Logistic Regression between Noise Level, Age, Use of Earplugs, Body Mass Index, Duration of Noise Exposure and Systolic Blood Pressure

\begin{tabular}{|c|c|c|c|c|c|c|}
\hline \multirow[b]{2}{*}{ Workers Characteristic } & \multicolumn{3}{|c|}{ Systolic Blood Pressure } & \multirow[b]{2}{*}{$\mathbf{O R}$} & \multirow[b]{2}{*}{$\mathbf{p}$} & \multirow[b]{2}{*}{ 95\%CI } \\
\hline & $\begin{array}{l}\leq 120 \\
\mathrm{n}(\%)\end{array}$ & $\begin{array}{l}>120 \\
\text { n (\%) }\end{array}$ & $\begin{array}{l}\text { Total } \\
\text { n (\%) }\end{array}$ & & & \\
\hline Noise level (dBA) & & & & 7.202 & $0.001^{*}$ & $2.304-22.509$ \\
\hline$\leq \mathrm{TLV}$ & $61(75 \cdot 3)$ & $20(24.7)$ & $81(100)$ & & & \\
\hline$>\mathrm{TLV}$ & $59(59.6)$ & $40(40.4)$ & $99(100)$ & & & \\
\hline Age (years old) & & & & 4.390 & $0.001^{*}$ & $1.801-10.701$ \\
\hline$\leq 40$ & $91(85.0)$ & $16(15.0)$ & $107(100)$ & & & \\
\hline$>40$ & $29(39.7)$ & $44(60.3)$ & $73(100)$ & & & \\
\hline Use of earplugs & & & & 12.675 & $0.000^{*}$ & $3.932-40.845$ \\
\hline Using & $57(77.0)$ & $17(23.0)$ & $74(100)$ & & & \\
\hline Not using & $63(59.4)$ & $43(40.6)$ & $106(100)$ & & & \\
\hline Body mass index $\left(\mathrm{kg} / \mathrm{m}^{2}\right)$ & & & & 5.262 & $0.000^{*}$ & $2.196-12.606$ \\
\hline Ideal & $86(82.7)$ & $18(17 \cdot 3)$ & $104(100)$ & & & \\
\hline Overweight & $34(44.7)$ & $42(55 \cdot 3)$ & $76(100)$ & & & \\
\hline $\begin{array}{l}\text { Duration of noise exposure } \\
\text { (years) }\end{array}$ & & & & 3.538 & $0.016^{*}$ & $1.266-9.834$ \\
\hline$\leq 10$ & $69(87.3)$ & $10(12.7)$ & $79(100)$ & & & \\
\hline$>10$ & $51(50.5)$ & $50(49.5)$ & $101(100)$ & & & \\
\hline
\end{tabular}


Table 3 Results of the Multiple Logistic Regression between Noise Level, Age, Use of Earplugs, Body Mass Index, Duration of Noise Exposure and Diastolic Blood Pressure

\begin{tabular}{|c|c|c|c|c|c|c|}
\hline \multirow[b]{2}{*}{ Workers Characteristic } & \multicolumn{3}{|c|}{ Diastolic Blood Pressure } & \multirow[b]{2}{*}{ OR } & \multirow[b]{2}{*}{$\mathbf{p}$} & \multirow[b]{2}{*}{$95 \% \mathrm{CI}$} \\
\hline & $\begin{array}{c}\leq 80 \\
n(\%)\end{array}$ & $\begin{array}{c}>80 \\
\text { n (\%) }\end{array}$ & $\begin{array}{l}\text { Total } \\
\text { n (\%) }\end{array}$ & & & \\
\hline $\begin{array}{l}\text { Noise level (dBA) } \\
\quad \leq \text { TLV } \\
>\text { TLV }\end{array}$ & $\begin{array}{c}65(80.2) \\
61(61.6)\end{array}$ & $\begin{array}{l}16(19.8) \\
38(38.4)\end{array}$ & $\begin{array}{l}81(100) \\
99(100)\end{array}$ & 6.105 & $0.001^{*}$ & $2.043-18.241$ \\
\hline $\begin{array}{l}\text { Age (years old) } \\
\quad \leq 40 \\
\quad>40\end{array}$ & $\begin{array}{l}96(89.7) \\
30(41.1)\end{array}$ & $\begin{array}{l}11(10.3) \\
43(58.9)\end{array}$ & $\begin{array}{c}107(100) \\
73(100)\end{array}$ & 6.606 & $0.000^{*}$ & $2.630-16.591$ \\
\hline $\begin{array}{l}\text { Use of earplugs } \\
\text { Using } \\
\text { Not using }\end{array}$ & $\begin{array}{l}57(77.0) \\
69(65.1)\end{array}$ & $\begin{array}{l}17(23.0) \\
37(34.9)\end{array}$ & $\begin{array}{c}74(100) \\
106(100)\end{array}$ & 12.675 & $0.000^{*}$ & $3.932-40.845$ \\
\hline $\begin{array}{l}\text { Body mass index }\left(\mathrm{kg} / \mathrm{m}^{2}\right) \\
\text { Ideal } \\
\text { Overweight }\end{array}$ & $\begin{array}{l}88(84.6) \\
38(50.0)\end{array}$ & $\begin{array}{c}16(15.4) \\
38(50.0)\end{array}$ & $\begin{array}{c}104(100) \\
76(100)\end{array}$ & 4.417 & $0.001^{*}$ & $1.813-10.765$ \\
\hline $\begin{array}{l}\text { Duration of noise exposure } \\
\text { (years) } \\
\quad \leq 10 \\
>10\end{array}$ & $\begin{array}{l}71(89.9) \\
55(54.5)\end{array}$ & $\begin{array}{c}8(10.1) \\
46(45.5)\end{array}$ & $\begin{array}{c}79(100) \\
101(100)\end{array}$ & 3.123 & $0.040^{*}$ & $1.055^{-9.243}$ \\
\hline
\end{tabular}

Note: *significant at 0.05

hearing protection devices, body mass index, and duration of noise exposure with systolic blood pressure all showed significant results $(\mathrm{p}<0.05)$. The full results are shown in Table 2.

All of the independent variables shown in Table 1 were further tested with multiple logistic regression analysis to determine their associations with diastolic blood pressure. The relationship between noise level, age, use of hearing protection devices, body mass index, and duration of noise exposure with diastolic blood pressure all showed significant results $(\mathrm{p}<0.05)$. The full results are shown in Table 3.

Predictor variables (noise level, age, use of earplugs, body mass index, and duration of noise exposure) contribute to systolic blood pressure amounted to $53.3 \%$. Similarly, the predictor variables (noise level, age, use of earplugs, body mass index, and duration of noise exposure) contribute to diastolic blood pressure was $53.2 \%$. The complete result of the contribution of predictor variables to systolic and diastolic blood

Table 4 Contribution of Predictor Variables to Systolic and Diastolic Blood Pressure

\begin{tabular}{llcc}
\hline Predictors & Predicted & Adjusted $\mathbf{R}^{\mathbf{2}}$ & $\mathbf{\%}$ \\
\hline $\begin{array}{l}\text { Noise level } \\
\text { Age }\end{array}$ & Systolic blood pressure & 0.533 & 53.3 \\
Use of earplugs & & & \\
$\begin{array}{l}\text { Body mass index } \\
\text { Duration of noise exposure }\end{array}$ & & & \\
$\begin{array}{l}\text { Noise level } \\
\text { Age }\end{array}$ & Diastolic blood pressure & 0.532 & 53.2 \\
Use of earplugs & & & \\
Body mass index & & & \\
Duration of noise exposure & & & \\
\hline
\end{tabular}


pressure was shown in Table 4.

\section{Discussion}

Based on the results of this study, the highest risk factor for increased blood pressure is workers who don't use earplugs continuously. In this study, the prevalence of workers exposed to noise exceeding TLV with high blood pressure was 40.4\% and exposure to noise below TLV 24.7\%. The prevalence of high blood pressure in workers who used earplugs continuously was $23.0 \%$ lower than the prevalence of high blood pressure in workers who did not use earplugs which is $40.6 \%$. Based on the results of this study the use of earplugs may lower the risk of increased blood pressure in workers. The results of this study similar to previous research by Saryawati ${ }^{15}$ in Semarang, which showed the prevalence of workers exposed to noisy textile industry was $85.7 \%$ and exposed to noise below TLV 21.9\%. The prevalence of high blood pressure in workers using earplugs was $38.9 \%$ lower than the prevalence of high blood pressure in workers who didn't use earplugs which is $42.9 \%$.

Noise is an environmental stressor; if the intensity exceeds the threshold limit value, it can lead to stress. The primary neural response to stress is the activation of the sympathetic nervous system. The hypothalamus helps to prepare the body to fight the stress stimulation. Blood containing angiotensinogen produced in the liver, by the hormone renin (produced by the kidney) converted to angiotensin I; By ACE (angiotensin I-converting enzyme) contained in the lungs, angiotensin I converted to angiotensin II. Angiotensin II increases the secretion of antidiuretic hormone (ADH) and thirst. ADH is produced in the hypothalamus (pituitary gland) and works on the kidneys to regulate osmolality and urine volume. By increasing $\mathrm{ADH}$, very little urine is excreted out of the body (antidiuretic), that it becomes concentrated and high in osmolality. By diluting, the extracellular fluid volume increased by drawing fluid from the intracellular portion, and as a result, blood volume increases, which in turn increases blood pressure. ${ }^{16}$ The use of earplugs will protect the intensity of noise received by auditory function up to $33 \mathrm{dBA}$, that the level of stress due to noise be reduced. ${ }^{17}$

Obesity associated with hypertension. ${ }^{18}$ People who are obese, their heart works harder in pumping blood. The blood vessels of fat people squeezed in the fatty skin that leads to an increase in blood pressure. ${ }^{19}$

The incidence of hypertension increases with age. ${ }^{20}$ As age increases, there will be a decrease in elasticity in the blood vessels so blood pressure will automatically rise. Both systolic blood pressure and diastolic blood pressure increase with age. Systolic blood pressure progressively increases until age $70-80$ years, whereas diastolic blood pressure rises until age 50-60 years and then tends to persist or slightly decreases. The combination of these changes is likely to reflect the recognition of blood vessels' and reduced arterial compliance. This results in an increase in blood pressure according to age. ${ }^{21}$

The results of this study indicate that all risk factors studied were associated with increased systolic and diastolic blood pressure. The four most significant independent variables that influence the increase in systolic blood pressure sequentially were: 1) use of earplugs, 2) noise level (Leq), 3) body mass index, and 4) age, respectively. While the four largest independent variables that influence the increase in diastolic blood pressure sequentially were: 1) use of earplugs, 2) age, 3) noise level (Leq), and 4) body mass index. The similarity is that indiscipline in hearing impairment is a major cause of increased systolic blood pressure and diastolic blood pressure, and duration of noise exposure is the least independent variable of the increase in systolic blood pressure and diastolic blood pressure.

The results of this study are similar with the research of Lee et al..$^{22}$ Stating that there was a significant relationship between chronic noise exposure and increased systolic blood pressure at a metal manufacturing company in Busan, Korea. Similarly, according to research by Zamanian et al. ${ }^{23}$ which examined the effect of steel industry noise exposure with the intensity of 85,95 , and $105 \mathrm{dBA}$ for 5 minutes to blood pressure and heart rate in 50 industrial workers in Iran. The results showed that with 5 min exposure there was an increase in blood pressure however it was statistically insignificant. ${ }^{23}$ Kalantary et al. ${ }^{12}$ stated that significant differences in blood pressure (systolic and diastolic) between the unexposed groups (exposure to $53 \mathrm{dBA}$ noise) and exposed group (exposed to noise 85-108 dBA occurred. The results of this study are also in line with the research of Chen et al. ${ }^{24}$ which stated exposure to 
the noise intensity of $87.5 \mathrm{~dB}(\mathrm{~A})$, the duration of noise exposure of 4.21 years and a CNE of $92.28 \%$ increased systolic and diastolic blood pressure of labors.

The noncompliance of using earplugs when working is the main factor for increasing of blood pressure. This result differs from that of Chen et al. ${ }^{24}$ that states there was no significant difference in the prevalence of hypertension among subjects using earplugs and those not using earplugs, and between continuous and non-continuous noise categories $(p>0.05)$. The use of disciplined earplugs on workers can statistically decrease the level of exposure to noise received..$^{25}$ By using earplugs for two weeks, the average systolic blood pressure dropped $5.70 \mathrm{mmHg}(\mathrm{p}=0.004)$, and the mean of diastolic blood pressure fell $2.13 \mathrm{mmHg}$ $(p=0.05)$. Thus, recommending workers to use hearing protection equipment in noisy working environments, in addition to reducing the effect of noise on the hearing system, can also reduce the impact of noise on the cardiovascular system..$^{26}$ In addition to earplugs, the use of personal protective equipment can protect the negative impacts of working environment hazards. Ramdan et al. ${ }^{27}$ stated that personal protective equipment (PPE) significantly associated with photokeratoconjunctivitis symptoms $(p=0.004)$ and Respati et al. ${ }^{28}$ concluded that the use of face-masks is related to the knowledge about byssinosis $(\mathrm{p}=0.001)$.

The significant association between age and blood pressure from the results of this study is in line with previous research which states that one of 1,729 peoples of petrochemical and gas refinery workers in Rio de Janeiro, Brazil. ${ }^{29}$ Similarly, with an opinion that suggests getting older, the higher the likelihood of developing high blood pressure. As we age, blood pressure increases gradually as the elasticity of the vessels diminishes. ${ }^{30}$ The age and family history are uncontrollable risk factors for high blood pressure..$^{11}$ The risk of high blood pressure increases with age, middle age, or around the age of 45 years..$^{21}$ Increased blood pressure with age is mainly due to structural changes in the arteries and especially with large arterial stiffness. Various studies indicated that increased blood pressure associated with an increased risk of cardiovascular diseases. ${ }^{21}$ The likelihood of hypertension rises steadily with age in three different populations (Ethiopia, Vietnam, and Indonesia). The age group of 45-54 and 55-64 years has a much higher chance of hypertension than the youngest age group of 25-34 years..$^{32}$ The description suggests that increasing age associated with increased blood pressure, and an increase will be seen after a person is over 45 years of age.

The relationship between body mass index with systolic and diastolic blood pressure was statistically significant; this suggests that obesity and high blood pressure are highly correlated even in old age. Reducing the rate of hypertension by weight change is possible. ${ }^{33}$ Body mass index is directly related to the systolic and diastolic blood pressure levels significantly. The prevalence of hypertension ( $\geq 140 / 90 \mathrm{mmHg}$ ) was higher in men compared with women significantly, and subjects who were obese and overweight compared with subjects with healthy weight differed significantly. ${ }^{34}$

The results of this study indicate that duration of noise exposure significantly correlated with systolic blood pressure and diastolic blood pressure. The results of this study are in line with the research Wang et al. ${ }^{35}$ which states that blood pressure was significantly increased with working years growing in noisy group. Only in noisy group, ECG among workers worked 10-year were significantly higher than those who worked o-year and workers who worked more than 15 years increased, which indicating that prolonged exposure to noise is a risk factor for high blood pressure. The National Institute for Occupational Safety and Health (NIOSH) specifies a maximum allowable daily noise dose, expressed in percentages, a person continuously exposed to $85 \mathrm{~dB}(\mathrm{~A})$ over an 8-hour work shift will reach $100 \%$ of their daily noise dose, if the exposure level increases to $88 \mathrm{~dB}(\mathrm{~A})$, workers should only be exposed for four hours. Alternatively, for every 3 - $\mathrm{dB}$ decrease in noise level, the allowable exposure time is doubled. ${ }^{36}$

Recommendations for the prevention of hypertension in workers are noise control, rotation of workers aged over 40 years working in non-noisy departments, disciplined workers using earplugs, maintaining a healthy diet, and workers who work more than ten years rotated to departments that not noisy.

\section{Conclusion}

Based on the evidence above it can be concluded that the risk factors of increased blood pressure in textile industry workers are the noise level, 
use of earplugs, age, and body mass index, and duration of noise exposure.

\section{Conflict of Interest}

The authors declare no conflict of interests.

\section{References}

1. Basner M, Babisch W, Davis A, Brink M, Clark C, Janssen S, et al. Auditory and nonauditory effects of noise on health. Lancet. 2014;383(9925):1325-32.

2. Selander J, Nilsson ME, Bluhm G, Rosenlund M, Lindqvist M, Nise G, et al. Long-term exposure to road traffic noise and myocardial infarction. Epidemiology. 2009;20(2):2729.

3. Kim S, The Healthline Editorial Team. High blood pressure symptoms. February 5, 2016 [cited 2017 April 3]. Available at: http:// www.healthline.com/health/high-bloodpressure-hypertension-symptoms.

4. Lim SS, Vos T, Flaxman AD, Danaei G, Shibuya K, Adair-Rohani H, Amann M, et al. A comparative risk assessment of burden of disease and injury attributable to 67 risk factors and risk factor clusters in 21 regions, 1990-2010: a systematic analysis for the Global Burden of Disease Study 2010. Lancet. 2012;380(9859):2224-60.

5. Campbell NRC, Lackland DT, Niebylski ML, World Hypertension League Committee; International Society of Hypertension Executive Committee. High blood pressure: why prevention and control are urgent and important: a 2014 fact sheet from the World Hypertension League and the International Society of Hypertension. J Clin Hypertens (Greenwich). 2014;16(8):551-3.

6. Ahmed AA, Awadalkarim MA. Noise exposure in two textile plants in Sudan. Eur Sci J. 2015;11(5):188-95.

7. Jayawardana TSS, Perera MYA, Wijesena GHD. Analysis and control of noise in a textile factory. Int J Sci Res Publ. 2014;4(12):1-7.

8. Ashraf HD, Younus MA, Kumar P, Siddiqui MT, Ali SS, Siddiqui MI. Frequency of hearing loss among textile industry workers of weaving unit in Karachi, Pakistan. J Pak Med Assoc. 2009;59(8):575-9.

9. Roozbahani MM, Nassiri P, Shalkouhi PJ. Risk assessment of workers exposed to noise pollution in a textile plant. Int $\mathrm{J}$ Environ Sci Tech. 2009;6(4):591-6.

10. Kishore J, Gupta N, Kohli C, Kumar N. Prevalence of hypertension and determination of its risk factors in rural Delhi. Int J Hypertens. 2016;2016:7962595.

11. Islam SM, Mainuddin A, Islam MS, Karim MA, Mou SZ, Arefin S, et al. Prevalence of risk factors for hypertension: a cross-sectional study in an urban area of Bangladesh. Glob Cardiol Sci Pract. 2015;2015(4):43.

12. Kalantary S, Dehghani A, Yekaninejad MS, Omidi L, Rahimzadeh M. The effects of occupational noise on blood pressure and heart rate of workers in an automotive parts industry. ARYA Atheroscler. 2015;11(4):2159.

13. Malekzadeh MM, Etemadi A, Kamangar F, Khademi H, Golozar A, Islami F, et al. Prevalence, awareness and risk factors of hypertension in a large cohort of Iranian adult population. J Hypertens. 2013;31(7):136471.

14. Santos J, Meira KC, Nascimento JOV, Da Costa ASSP, Dos Santos LT, Pierin AMG. Hypertension in nursing professionals working in oncology: prevalence and associated factors. $\mathrm{J}$ Hypertens. 2015;33(e-Suppl 1):e254.

15. Saryawati R. Faktor risiko kejadian hipertensi pada pekerja industri tekstil (thesis). Semarang: Universitas Diponegoro; 2008.

16. Hall JE. Guyton and Hall textbook of medical physiology. $13^{\text {th }}$ edition. Philadelphia: Elsevier Inc.; 2016.

17. Mitchem D. Hearing protection fit-testing (thesis). Morgantown: West Virginia University; 2012.

18. Re RN. Obesity-related hypertension. Ochsner J. 2009;9(3):133-6.

19. Woolston C. Obesity and heart disease. Last updated: Jan 20, 2017 [cited 2017 April 3]. Available from: https://consumer.healthday. com/encyclopedia/heart-health-22/miscstroke-related-heart-news-36o/obesity-andheart-disease-644588.html.

20. Stockslager L, Schaeffer L. Buku saku asuhan keperawatan geriatri. Edisi ke-2. Jakarta: EGC; 2007.

21. Pinto E. Blood pressure and ageing. Postgrad Med J. 2007;83(976):109-14.

22. Lee JH, Kang W, Yaang S, Choy N, Lee C. Cohort study for the effect of chronic noise 
exposure on blood pressure among male workers in Busan, Korea. Am J Ind Med. 2009;52(6):509-17.

23. Zamanian Z, Rostami R, Hasanzadeh J, Hashemi H. Investigation of the effect of occupational noise exposure on blood pressure and heart rate of steel industry workers. J Environ Public Health. 2013;2013:256060.

24. Chen S, Ni Y, Zhang L, Kong L, Lu L, Yang Z, et al. Noise exposure in occupational setting associated with elevated blood pressure in China. BMC Public Health. 2017;17(1):107.

25. Chang TY, Hwang BF, Liu CS, Chen RY, Wang VS, Bao BY, et al. Occupational noise exposure and incident hypertension in men: a prospective cohort study. Am J Epidemiol. 2013;177(8):818-25.

26. Pouryaghoub GH, Haghighi KS, Sabzalian F. Assessment of the effect of personal protective devices on blood pressure and pulse rate in a noisy environment. Occup Med J. 2009;1(1):33-6.

27. Ramdan IM, Mursyidah SB, Jubaedah S. Photokeratoconjunctivitis symptoms among informal welding operators in North Samarinda, Indonesia. GMHC. 2017;5(2):144-51.

28. Respati T, Ibnusantosa G, Rachmawati M. Knowledge about byssinosis and the use of face-masks. GMHC. 2013;1(1):3-8.

29. de Souza TCF, Périssé ARS, Moura M. Noise exposure and hypertension: investigation of a silent relationship. BMC Public Health. 2015;15:328.

30. American Heart Association. Understanding and managing high blood pressure. 2014 [cited 2017 April 3]. Available from: http:// dhhs.ne.gov/publichealth/WMHealth/ Documents/Understanding_Managing_ HBP.pdf.

31. Centers for Disease Control and Prevention. High blood pressure risk factors. Page last updated: July 7, 2014 [cited 2017 April 3]. Available from: https://www.cdc.gov/ bloodpressure/risk_factors.htm.

32. Tesfaye F, Nawi NG, Van Minh H, Byass $\mathrm{P}$, Berhane Y, Bonita R, et al. Association between body mass index and blood pressure across three populations in Africa and Asia. $\mathrm{J}$ Hum Hypertens. 2007;21(1):28-37.

33. Dua S, Bhuker M, Sharma P, Dhall M, Kapoor S. Body mass index relates to blood pressure among adults. N Am J Med Sci. 2014;6(2):89-95.

34. Papathanasiou G, Zerva E, Zacharis I, Papandreou M, Papageorgiou E, Tzima C, et al. Association of high blood pressure with body mass index, smoking and physical activity in healthy young adults. Open Cardiovasc Med J. 2015;9:5-17.

35. Wang S, Qin Q, Liu L, Han L, Chen Y. A cross-sectional study on the effects of occupational noise exposure on hypertension or cardiovascular among workers from automobile manufacturing company of Chongqing, China. J Biomed Sci Eng. 2013;6(12):1137-42.

36. Kardous C, Themann CL, Morata TC, Lotz WG. Understanding noise exposure limits: occupational vs. general environmental noise. Posted on February 8, 2016 [cited 2017 April 3]. Available from: https://blogs.cdc. gov/niosh-science-blog/2016/02/o8/noise/. 